\title{
A INEXISTENCIA DO FORTE DE NOSSA SENHORA DO PÓPULO E SÃO MARCELO AO TEMPO DA INVASÃO HOLANDESA DA BAHIA, EM 1624.
}

Ponto pacífico por excelência foi, até bem pouco tempo atrás, a participação acentuada do atual Forte do Mar da Bahia, tamyém chamado de Nossa Senhora do Pópulo e São Marcelo, nas lutas contra o invasor holandês, pela éra de 1624 .

Estudiosos contemporâneos, a cujo número não fiz exceção, imbraram sempre em realçar, una voce, o papel saliente desempenhado por aquela bastilha nos duros embates que culminaram com a queda da primitiva capital brasileira em poder dos batavos, no primeiro quartel seiscentista .

Assegurava-se que fôra após o assalto frustrado de 1604, quando o corsário neerlandês Paulus van Caarden acometera a Cidade do Salvador, e tentara repetidamente em vão conquistála, que surgira a idéia de fortificar o ilhéu existente no ancoradouro, fronteiro àquela metrópole, cabendo a Diogo Botelho dar os primeiros passos em tal sentido, a partir de 1606 .

Dizia-se ainda ter sido Francisco de Frias da Mesquita, quem lhe traçara a primitiva planta, de feitio triangular, e que, durante o período governamental de Diogo de Mendonça Furtado (1621-1624), a anteceder de imediato a grande incursão flamenga sob o comando de Jacob Willekens, se tratou de ultimá-lo a todo o pano, não se chegando a conseguir isso antes da vinda dos assaltantes alienígenas.

No ano de 1954, certo pesquisador das fortificações coloriiais bahianas, Luís Menezes Monteiro da Costa, ao preparar tese de concurso para a cátedra de História do Brasil do Instituto Normal da Bahia, tomou como tema as "Certidões de Nascimento da Fortaleza de Nossa Senhora do Pópulo". Analisando o alvará de 1606 e a carta-régia de 1622, os quais induziram em êrro a totalidade dos historiadores brasileiros, e sobretudo os baianos, taxou-os a ambos de certidões falsas. Colhendo achegas valiosas em documentos coevos, teceu considerações de maneira a comprovar que o tão citado forte sôbre a lagem, den- 
tro do mar, próximo à Ribeira das Naus, da época das invasões holandesas, não correspondia ao atual São Marcelo e sim ao propugnáculo dedicado a São Felipe e São Tiago e a Nossa Senhora da Conceição, o qual desapareceu sem deixar vestígios, apagando-se por completo a memória dos seus feitos relevantes, com o rolar do tempo.

Apontou Monteiro entre outros elementos subsidiários de sua tese a estampa holandesa seiscentista, a narrar o assalto de Pieter Heyn à Bahia, em 1627, reproduzida à pág. 33 do AlbumLembrança da Exposição Iconográfica e Bibliográfica Bahiana, editado pela Prefeitura Municipal do Salvador em 1951, na qual figura, além do castelo marítimo de forma triangular, próximo à praia, tido e havido como a primitiva matriz do São Marcelo, determinado banco de areia (Vlate) que corresponde mais precisamente à atual situação dêste último. Em verdade, a representação lado a laḍo dos dois elementos em questão era indício muito seguro de que a razão assistia a Monteiro, se já não bastassem os demais argumentos lógicos por êle aduzidos no sentido de mostrar que o forte da praia, sôbre a lagem, cercado de água por todos os lados, não podia ser de maneira alguma o que veio a batizar-se mais tarde Nossa Senhora do Pópulo. Este nasceu muito depois do período das invasões batavas, no govêrno do Conde de Castelo Melhor, ou seja, a partir de 1650 .

A tese de Monteiro não teve, até agora, ao que me consta, o beneplácito dos historiadores bahianos, aferrados à estampa muito divulgada de Claes Jansz, Fisscher, a datar de 1624 e a ilustrar a relação da conquista, apresentada pelo Almirante Willekens. Nesse panorama descritivo do assalto da esquadra holandesa às plagas soteropolitanas, nota-se, na verdade, uma fortaleza triangular, dentro do mar, em posição que muito se aproxima do atual São Marcelo. Todavia, esqueceram-se os referidos historiadores que semelhante gravura não obedece a nenhuma escala métrica rigorosa, cabendo à fantasia do desenhista figurar os propugnáculos onde bem lhe aprouve.

Ao rever e comentar a tradução portuguêsa da famosa Relação da Conquista e Perda da Cidade do Salvaldor pelos Holandeses em 1624-1625, de autoria de Johan Gregor Aldenburgk, feita por Alfredo de Carvalho em 1913 e calcada na primeira edição alemã do livro em apreço, datada de 1627 , em via de publicação sob minha responsabilidade, deparei com um trecho que dá absoluto ganho de causa à tese de Monteiro. Trata-se da seguinte passagem à pág. 51 da edição em questão, correspondente ao item marginal 164, sob o título "Insul": 
"Bald auff dieses wurde Capitän Ernst Kiff vnnd Merlein mit 150. Soldaten an eine Insul gleich S. Salvador über, welche ein halber Cartaumenschuss gantz überspielen kundte, commandiret, diese kleine Insul bawete vnd bewohnete ein Bandit. Als nun Gott gute Früchte vnd Westwind bescheret, vervrsacht dieses, dass wir den curs wider zu der Bahje nahmen".

Reza a versão portuguêsa dêste trecho:

"Quase em séguida, os capitães Ernst Kiff e Merlein foram enviados, com cento e cinqüenta soldados, a uma ilha situada bem em frente da Cidade do Salvador, na distância de um tiro de bombarda, a qual ilhota (1) era habitada e cultivada por um degredado. Mas, como Deus só nos concedesse boas frutas e vento do Oeste, resultou que retomássemos o rumo da Bahia".

Que ilhota existia então com a situação descrita pelo cronista-testemunha ocular da invasão batava de 1624, senão o pequeno banco de terra arável, e não de pedra, onde hoje 'se assenta o Forte de São Marcelo? Era êsse trato de chão habitado e cultivado por um degredado e nenhuma fortificação encerrava na ocasião. Apesar da clareza e evidência do texto de Aldenburgk, localizando-o à distância de um tiro de bombarda e bem defronte da Cidade do Salvador, poderia alguém admitir que se tratasse da Ilha de Itaparica no caso. Entretanto, tal dúvida se dissipa prontamente, quando na página imediata o autor seiscentista alude, sob a rubrica marginal 173, intitulada Insul Taberica, à expedição levada a efeito na direção dessa outra, mencionando-a de forma especial, a saber:

"Wir namen vnsern curs. Westlichen an auff eine schöne Insul, die hiess Taberica, vnd legeten in der Nacht vnter wall Ancker",

cuja tradução se segue:

"Tomamos rumo de Oeste, em direção a uma formosa ilha, chamada Itaparica, e ali passamos a noite, fundeados próximo à ribeira".

Outra passagem de Aldenburgk que corrobora o ponto de vista de Monteiro, encontra-se à pág. 58, quando êle declara:

(1). - o grifo é meu. 
"Die Soldaten musten Tag vnd Nacht schantzen vnd wercken, vnsere Schiff wurden all vnterwall, so weit man kundete, dessgleichen auch die Brandschiffe gecurtet, vnd buxiret. Wir legeten 5 . vnd 5 . Schiffe neben den grossen Fort in dem Meer zusammen, schlugen allenthalben am Land, wo paschaschi, pallisaden, stageeden, vnd richteten trenchee $\mathrm{zu}^{\prime \prime}$.

Em língua portuguêsa:

"Os soldados tiveram de trabalhar dia e noite nas trincheiras; nossos navios foram todos aproximados o mais possível da ribeira, e bem assim rebocados os brulotes; de cada lado do Forte do Mar ancoramos cinco navios (2), e, por tôda a parte em terra levantamos parapeitos, paliçadas, trincheiras e tôda a casta de obras de defesa".

O forte do mar junto à ribeira, do trecho em causa, nunca -poderia ser o atual São Marcelo.

Como se acaba de verificar, não haverá depoimento mais fidedigno e autorizado do que a palavra de Aldenburgk, no sentido de restituir-se ao Forte de São Felipe e São Tiago o papel desempenhado e atribuído até há pouco ao nosso vetusto São Marcelo.

EDGARD DE CERQUEIRA FALCÃO

(2). - Os diferentes trechos grifados desta citação o foram por mim. 